\title{
Sustainable utilization of edible fruits by Tangkhul Naga Tribe in Ukhrul District, Manipur, North-east India
}

\author{
S. Salam ${ }^{1,5}$, A. Pinokiyo ${ }^{2}$, M. Roma ${ }^{3}$ and N. S. Jamir ${ }^{4}$ \\ ${ }^{1}$ Department of Botany, Nambol L. Sanoi College, Nambol-795134, Manipur, India \\ ${ }^{2}$ Department of Botany, D.M. College of Science, Imphal-795001, India \\ ${ }^{3}$ Department of Botany, Kha Manipur College, Kakching, Manipur, India \\ ${ }^{4}$ Department of Nagaland University, Headquarters: Lumami, Mokokchung-798601, Nagaland Botany, India \\ ${ }^{5}$ Corresponding author; e-mail: sumitrasalam@gmail.com
}

[Received 30.05.2019; Revised 20.06.2019; Accepted 26.06.2019; Published 30.06.2019]

\begin{abstract}
Ukhrul district of Manipur is mainly inhabited by Tangkhul Naga tribe. This tribe often uses an enormous range of wild plants to meet their daily requirements. An extensive survey was conducted to document the wild edible fruits used by this community during the years, 2011, 2012, 2013 in Ukhrul district, Manipur. From this study, a total of 25 Angiosperm plant species belonging to 23 genera and 17 families have been recorded. Most of these fruits are freshly consumed while some are taken in the form of pickles, juice, jam, candies, etc. More interestingly, some selected fruits are fermented and used as fruit beer. This fruit beer is offered after dinner in every household. Nowadays, it serves as important source of household income for the Tangkhul community. Among the fruits Phyllanthus officinales, Ficus cunea, Musa sapientum, Prunus cerosoides, $P$. nepaulensis, etc. are considered as income generating fruits as indigenous fruit beer are also prepared from this fruits. Many wild fruits that are abundantly found in their locality are also sold in local markets. Plantation of these fruit yielding plants in home gardens and farm areas has shown its commercial potential and steps for conserving economically significant diverse plants of this hilly region in a sustainable way. Thus the study reveals sustainable utilization of edible fruits by Tangkhul Naga Tribe of Ukhrul district, Manipur.
\end{abstract}

Key words: Edible fruits, Tangkhul tribe, Ukhrul, Sustainable, Fruit beer

\section{INTRODUCTION}

Ukhrul district which is the main home land of Tangkhul Naga tribe, makes its boundaries with the state of Nagaland in the North, Myanmar in the East, Chandel and Senapati districts of Manipur respectively in the South and West. It is situated in the Eastern part of Manipur state, India, covering an area of 4,544 $\mathrm{sq} \mathrm{km}$ with the population of 1,83,115 (Anonymous 2011) which lies in between $23 \mathrm{U} 132 \mathrm{~N}$ and $25 \mathrm{U}^{2} 68^{2} \mathrm{~N}$ latitudes and $94 \mathrm{U} 202 \mathrm{E}$ and 95Ú252 E longitudes and covering an altitudinal range of $913 \mathrm{~m}$ to $3114 \mathrm{~m}$ AMSL. The climate of the district is temperate in nature with a minimum and maximum temperature of $3^{0} \mathrm{C}$ to $33^{0} \mathrm{C}$. The Tangkhul people of this region are simple, brave, reliable, generous, sincere and friendly. The majority of the people are agriculturist; rice is the staple food of the people. Mostly they depend on various wild edible plants, which contain necessary food values of a balanced diet. Every household collects wild fruits and maintain the areas where it grows. Among the fruit plants Docynia indica, Myrica esculenta, Phyllanthus emblica, Prunus cerasoides, $P$. salicina, etc. are considered as income generating fruits which is used for the preparation of indigenous fruit beer. A very little work has been done on wild edible fruits of Manipur state. Sharma et al. (2000) reported edible fruits used by the 
Meitei community, and more recently Devi et al. (2012) reported edible fruits by Kabui tribe of Manipur. However, so far, no such attempt has been made to explore the wild edible fruit plants from this district. In the present paper, therefore, an attempt has been made by the authors to highlight certain unexploited wild fruit plants used by the Tangkhul tribe.

\section{METHODOLOGY}

In this study, an intensive ethnobotanical survey was conducted since 2011 among the Tangkhul-Naga tribe for gathering information on wild edible fruit plants traditionally used by them. At the begining, mandatory PIC was obtained from the village heads. Along with the information suitable plant specimens were also collected for scientific identification. The authenticity of the uses was repeatedly verified by asking to the different informer. In case of contradictory information, efforts were made to get the correct information. Tribal market (Litan, Lambui, Kamjong, Ukhrul,) were also visited frequently to study the fruits sold there. Collected specimens were processed into mounted Herbarium-sheets following Jain \& Rao (1977). The plants were identified with the help of published literature including, Hooker (1872 - 1897), Kanjilal et al (1934 - 1940), Singh \& Arora (1978). For updated nomenclature and the family delimitation www.theplantlist.org was consulted. One set of herbarium specimens have been deposited in the Herbarium of the Department of Botany, Nagaland University and another set in the Life Sciences Department of Manipur University.

\section{RESULTS}

In the present paper, botanical names are arranged alphabetically along with the family, vernacular names and mode of usage by the Tangkhul tribe is mentioned and shown in the Table1.

Table 1. Recorded wild edible plants of Tangkhul tribe and their mode of uses

\begin{tabular}{|c|c|c|c|}
\hline $\begin{array}{l}\text { Botanical name [Family]; } \\
\text { Exsiccatae }\end{array}$ & $\begin{array}{c}\text { Vernacular } \\
\text { name }\end{array}$ & Habit & Mode of use \\
\hline $\begin{array}{l}\text { Ananas comosus ( L.) Merr. } \\
\text { [Bromeliaceae]; Salam-505 }\end{array}$ & Chingomthei & Herb & $\begin{array}{l}\text { Eaten raw, jelly, juice, fruit } \\
\text { beer }\end{array}$ \\
\hline $\begin{array}{l}\text { Averrhoa carambola L. } \\
\text { [Oxalidaceae];Salam- } 962\end{array}$ & Heinoujam & Tree & Eaten raw, jam and candy \\
\hline $\begin{array}{l}\text { Calamus tenuis Roxb. } \\
\text { [Arecaceae] ; Salam- } 977\end{array}$ & Mathirathei & Climber & Eaten raw \\
\hline $\begin{array}{l}\text { Choerospondias axillaris (Roxb.) } \\
\text { B.L.Burtt \& A.W.Hill } \\
\text { [Anacardiaceae]; Salam-3558 }\end{array}$ & Khursongthei & Tree & Eaten raw \\
\hline Citrus sp. [Rutaceae]; Salam- 912 & Sagomthei & Small tree & Eaten raw \\
\hline $\begin{array}{l}\text { Docynia indica (Wall.) Decne. } \\
\text { [Rosaceae]; Salam- } 567\end{array}$ & Theithukthei & Tree & $\begin{array}{l}\text { Eaten raw, roasted, candy, } \\
\text { fruit beer }\end{array}$ \\
\hline $\begin{array}{l}\text { Elaeocarpus floribundus Blume } \\
\text { [Elaeocarpaceae]; Salam-906 }\end{array}$ & Fashongthei & Small tree & $\begin{array}{l}\text { Eaten raw or cooked, pickles } \\
\text { and fruit beer }\end{array}$ \\
\hline $\begin{array}{l}\text { Ficus semicordata Buch.-Ham. } \\
\text { ex Sm. [Moraceae]; Salam-594 }\end{array}$ & Heirit & Tree & Eaten raw, fruit beer \\
\hline $\begin{array}{l}\text { Garcinia pedunculata Roxb. ex } \\
\text { Buch.-Ham. [Clusiaceae]; Salam- } \\
919\end{array}$ & Theilungthei & Tree & Eaten raw, cooked, dried \\
\hline
\end{tabular}




\begin{tabular}{|c|c|c|c|}
\hline $\begin{array}{l}\text { Botanical name [Family]; } \\
\text { Exsiccatae }\end{array}$ & $\begin{array}{l}\text { Vernacular } \\
\text { name }\end{array}$ & Habit & Mode of use \\
\hline $\begin{array}{l}\text { Juglans regia L. [Juglandaceae]; } \\
\text { Salam- } 926\end{array}$ & Shirangthei & Tree & Dried mature fruits eaten raw \\
\hline $\begin{array}{l}\text { Morus nigra L. [Moraceae]; } \\
\text { Salam-1863 }\end{array}$ & Kaharathei & Tree & Eaten raw \\
\hline $\begin{array}{l}\text { Musa } x \text { paradisiaca L. } \\
\text { [Musaceae]; Salam-516 }\end{array}$ & Mothei & Herb & Eaten raw, fruit beer \\
\hline $\begin{array}{l}\text { Myrica esculenta } \text { Buch.-Ham. ex } \\
\text { D.Don [Myricaceae]; Salam-1867 }\end{array}$ & Mahuithei & Small tree & Eaten raw, fruit beer \\
\hline $\begin{array}{l}\text { Meyna spinosa } \text { Roxb. ex Link } \\
\text { [Rubiaceae]; Salam-1857 }\end{array}$ & Theibethei & Tree & Eaten raw \\
\hline $\begin{array}{l}\text { Passiflora edulis Sims } \\
\text { [Passifloraceae]; Salam- } 550\end{array}$ & Sitapor & Twinner & Eaten raw, fruit juice \\
\hline $\begin{array}{l}\text { Phoenix sylvestris (L.) Roxb. } \\
\text { [Arecaceae]; Salam- } 1883\end{array}$ & Khaneithei & $\begin{array}{l}\text { Under } \\
\text { shrub }\end{array}$ & $\begin{array}{l}\text { Kernel of the ripe fruits is } \\
\text { eaten raw }\end{array}$ \\
\hline $\begin{array}{l}\text { Phyllanthus emblica L. } \\
\text { [Phyllanthaceae]; Salam-1866 }\end{array}$ & Shakshathei & Tree & $\begin{array}{l}\text { Eaten raw, dried, pickles, fruit } \\
\text { beer }\end{array}$ \\
\hline $\begin{array}{l}\text { Prunus cerasoides Buch.-Ham. ex } \\
\text { D.Don [Rosaceae]; Salam-1874 }\end{array}$ & Saharthei & Tree & $\begin{array}{l}\text { Ripe blackish fruits are eaten } \\
\text { raw }\end{array}$ \\
\hline $\begin{array}{l}\text { P. napaulensis (Ser.) Steud. } \\
\text { [Rosaceae]; Salam- } 3529\end{array}$ & Theikanthei & Tree & Eaten raw, fruit beer \\
\hline $\begin{array}{l}\text { P. salicina Lindl. [Rosaceae]; } \\
\text { Salam- } 900\end{array}$ & Heikhathei & Tree & Eaten raw, fruit beer \\
\hline $\begin{array}{l}\text { Psidium guajava L. [Myrtaceae]; } \\
\text { Salam-554 }\end{array}$ & Pungdonrong & Tree & Eaten raw \\
\hline $\begin{array}{l}\text { Pyrus pashia } \text { Buch.Ham. ex } \\
\text { D.Don [Rosaceae]; Salam-3531 }\end{array}$ & Lam Kapaithei & Tree & Eaten raw \\
\hline $\begin{array}{l}\text { Rhus chinensis Mill. } \\
\text { [Anacardiaceae]; Salam3559- }\end{array}$ & Khamkhuithei & Tree & Eaten raw,juice,candy \\
\hline $\begin{array}{l}\text { Rubus ellipticus Sm. [Rosaceae]; } \\
\text { Salam- } 3540\end{array}$ & Karathei & Shrub & Eaten raw \\
\hline $\begin{array}{l}\text { Syzygium cumini (L.) Skeels } \\
\text { [Myrtaceae]; Salam-3566 }\end{array}$ & Chomshathei & Tree & Eaten raw, jam \\
\hline $\begin{array}{l}\text { Tamarindus indica L. } \\
\text { [Leguminosae]; Salam- - } 3568\end{array}$ & Mange & Tree & Eaten raw \\
\hline
\end{tabular}

During the current survey 25 Angiosperm plant species belonging to 23 genera and 10 families were recorded from different areas and local market of Ukhrul District. Majority of the plants are trees (20 spp.) followed by herbs ( $2 \mathrm{spp}$.), shrubs, climbers and under shrubs with one species each. The price of fruits in local markets fluctuate from season to season depending mainly on their availability. Some significant fruits and their fruit beer bottles are shown in Figures $1 \& 2$.

\section{DISCUSSION}

In addition to their daily meals, the Tangkhul people also mostly taken seasonal fresh fruits after every meal and have significant place in the dietary habits of Tangkhul community. Majority of the fruits are freshly consumed while some are taken in the form of pickles, juice, jam, candies, etc. The availability of fruit plants like Citrus maxima, Phyllanthus 

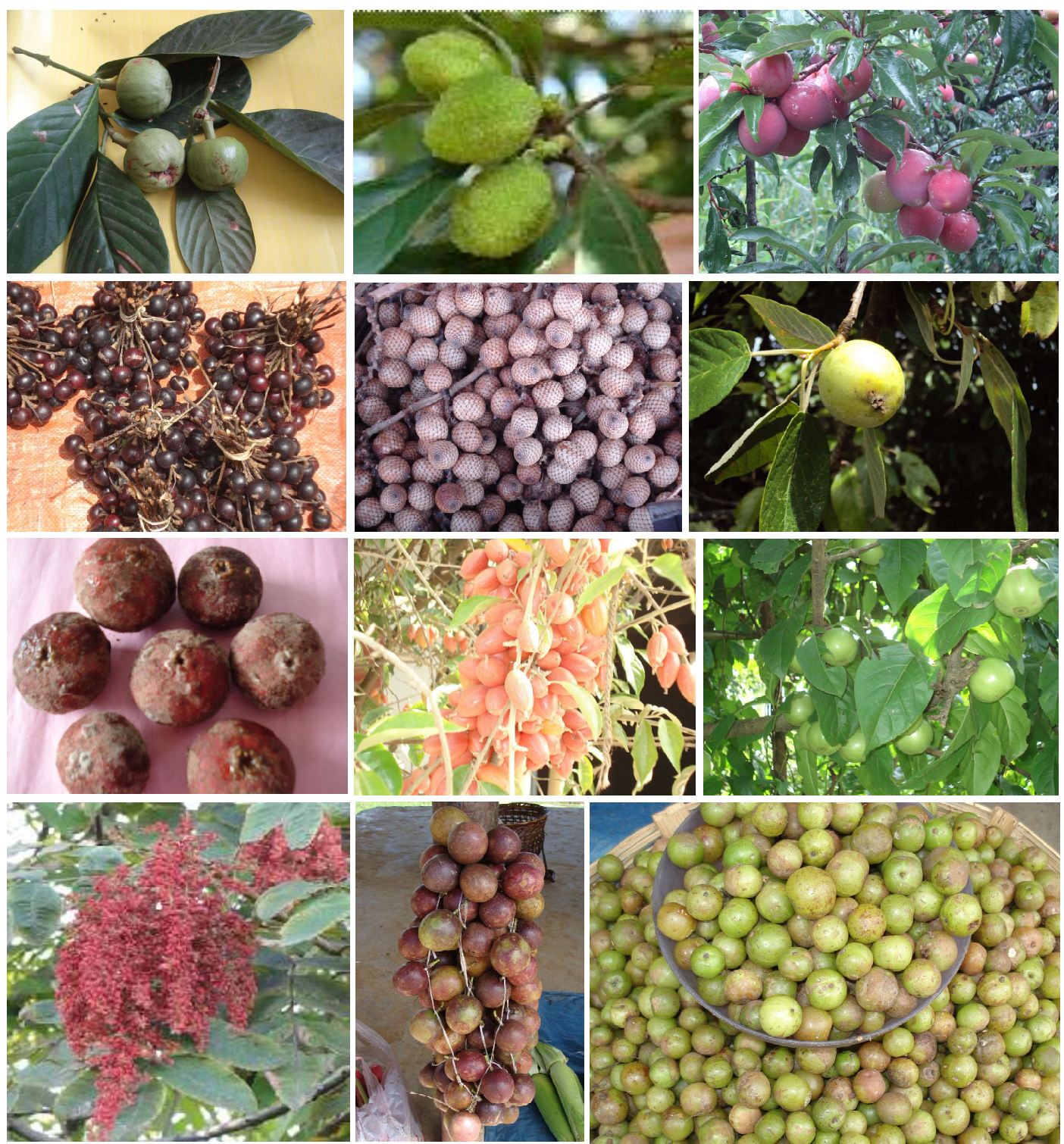

Figure 1. Wild edible fruits used by Tangkhul community in the Ukhrul district of Manipur: A. Garcinia pendunculata; B. Myrica esculenta; C. Prunus salicina; D. Prunus napaulensis; E. Calamus tenuis; F. Docynia indica; G. Ficus semicordata; H. Elaeocarpus floribundus; I. Meyna spinosa; J. Rhus chinensis; K. Passiflora edulis; L. Phyllanthus emblica

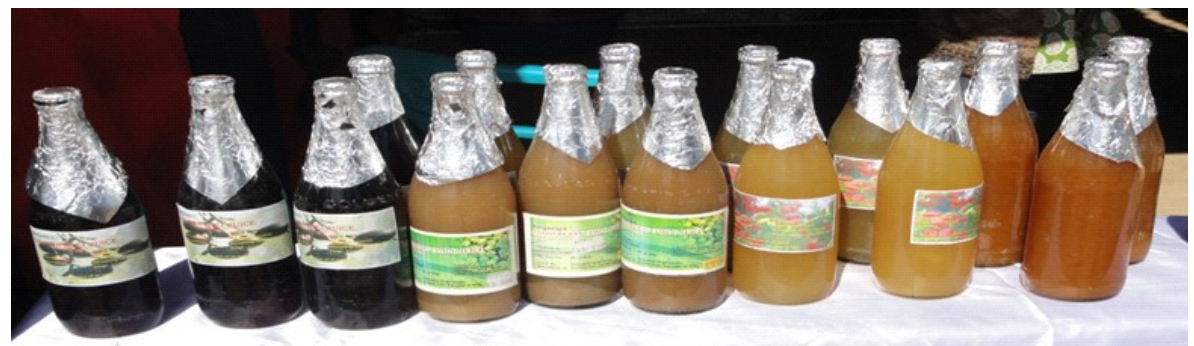

Figure 2. Locally produced fruit beer available in local markets of Ukhrul district 
emblica, Passiflora edulis, P. cerasoides, P. napaulensis etc. in the market is decreasing day by day due to over exploitation and people's increasing demand for daily consumption as well as for the preparation of traditional fruit beer to which these are raw materials. If proper strategies are proposed, including extensive cultivation of these fruit plants, these may become one important industry and will form a profitable part of Tangkhul economy. These fruits and fruit beer can also be marketed outside for better income generation. However, government and other local agencies need to come ahead with appropriate strategies.

\section{Conclusion}

During the study it was realised that the people of Tangkhul tribe has a rich stock of ethnic and traditional knowledge that need to be explored and recorded immediately. Further study in the district may lead to the recognition of many more wild edible fruits used by them. Emphasis must also be laid on the conservation on such plant wealth and their scientific exploitation. Their own knowledge can be their own way of improving the socio-economic conditions of this traditional community.

\section{Acknowledgements}

Authors are greatly indebted to the tribal people of Ukhrul district for revealing their valuable information. They are also thankful to Prof. P.K. Singh of Department of Life Sciences, Manipur University, Canchipur, for extending facilities and encouragement.

\section{LITERATURE CITED}

Anonymous 2011. Census of Manipur 2011. Directorate of Census Operations, Government of Manipur.

Devi, M.R.; Singh, P.K. \& Dutta, B.K. 2012. A case study on edible fruits used by the Kabui Naga Tribe of Manipur. Symposium Proceeding: Biodiversity status \& Conservation Strategies with reference to NE India.CAS in Life Sciences, Manipur University.Pp. 94 - 97.

Hooker, J.D. 1872 - 1897. Flora of British India, Vols. 1-7. L. Reeve \& Co Ltd, Ashford, Kent, London.

Jain, S.K. \& Rao, R.R. 1977. A Handbook of Field and Herbarium methods. Today andTomorrow's Printers and Publishers, New Delhi.

Kanjilal,U.N.; Kanjilal, P.C.; Das, A. \& Purkayastha, C. 1934. Flora of Assam. Vol. -I, Govt. of Assam, Shillong.

Kanjilal,U.N.; Kanjilal, P.C \& Das, A. 1936. Flora of Assam. Vol. -II, Govt. of Assam, Shillong.

Kanjilal,U.N.; Kanjilal, P.C \& Das, A. \& De, R.N . 1938. Flora of Assam. Vol. -III, Govt.of Assam, Shillong.

Kanjilal,U.N.; Kanjilal, P.C; De, R.N. \& Das, A. 1940. Flora of Assam. Vol. -IV, Govt. ofAssam, Shillong.

Singh, H.B. \& Arora, R.K. 1978. Wild Edible Plants of India. ICAR, NewDelhi.

Sharma, H.M.; Devi A.R. \& Sharma B.M. 2000. Contribution to the Edible Fruits of Manipur. In: J.K. Maheshwari (Ed.), Ethnobotany and Medicinal plants of Indian subcontinent. Scientific Publishers, Jodhpur, India. Pp. 615 - 623.

www.theplantlist.org [accessed on 20.05.2019] 